KITAKIWI MASINAHIKANAN (OUR MAP)

\author{
by \\ Joelle McNeil \\ MA, McMaster University, 2012 \\ BA, McGill University, 2010 \\ A Major Research Paper \\ Presented to Ryerson University
}

in partial fulfillment of the requirements for the degree of

\author{
Master of Planning \\ in \\ Urban Development \\ Toronto, Ontario, Canada, 2018
}

(c) Joelle McNeil 2018 


\section{Author's Declaration for Electronic Submission of a MRP}

I hereby declare that I am the sole author of this MRP. This is a true copy of the MRP, including any required final revisions.

I authorize Ryerson University to lend this MRP to other institutions or individuals for the purpose of scholarly research.

I further authorize Ryerson University to reproduce this MRP by photocopying or by other means, in total or in part, at the request of other institutions or individuals for the purpose of scholarly research.

I understand that my MRP may be made electronically available to the public. 


\title{
KITAKIWI MASINAHIKANAN (OUR MAP)
}

\author{
(C) Joelle McNeil, 2018 \\ Master of Planning \\ in \\ Urban Development \\ Ryerson University
}

\begin{abstract}
Members of Nibinamik First Nation, an Anishinaabe community in the Far North of Ontario, are in the process of updating their land use plan. As part of this land use planning project, Nibinamik seeks an accompanying and informing map of their traditional territory. Through a partnership between Nibinamik and Ryerson University, we explored the substantive and procedural values informing the mapping, and by extension the land use planning, project. The findings are discussed in relation to the literature on Indigenous counter-mapping and in reference to the guiding provincial policy framework. Importantly, Nibinamik seeks an alternate process to that imposed by the province, while simultaneously seeking recognition by the province. In this way, Nibinamik resists the province's claims to exclusive power over crown lands, and asserts claims to shared power over traditional territory.
\end{abstract}

Key words: counter-mapping; Indigenous Planning; northern Ontario 


\section{Acknowledgements}

First, I want to acknowledge the relationship between Ryerson University and Nibinamik First Nation that made this project possible.

I want to thank the community stakeholders who dedicated their time to this project, and to the community members of Nibinamik who inadvertently supported this work through welcoming me into the community during fieldwork. Special thanks to Tommy Yellowhead, Roger Oskineegish, and Walter Oskineegish.

I want to thank everyone at the Together Design Lab for their support with this project, especially Jeffrey Herskovits, Lara Hintelmann, and Courtney Kaupp. Special thanks to my supervisor, Dr. Shelagh McCartney, for seeing my potential, keeping me on my toes, and encouraging me to pursue my dreams.

Acknowledgement is due to my partner, Scott, for fueling my contributions to this project, literally through packed lunches, and figuratively through love and support. Thank you.

Last, I want to acknowledge the ongoing legacy of colonialism that informs the privilege with which I write, brings necessity to this work, and simultaneously restricts and motivates vision for a better future. 


\section{Tables of Contents}

LIST OF FIGURES

Executive Summary $\quad 1$

Project Summary 1

Summary Table: Values and Considerations $\quad 2$

$\begin{array}{ll}\text { Background } & 4\end{array}$

$\begin{array}{ll}\text { Policy Context } & 6\end{array}$

$\begin{array}{lr}\text { Maps and Power } & 9\end{array}$

Maps as a Tool of Empire $\quad 9$

$\begin{array}{ll}\text { Indigenous Counter-Mapping } & 10\end{array}$

$\begin{array}{ll}\text { Project Approach } & 13\end{array}$

$\begin{array}{ll}\text { Substantive and Procedural Values } & 14\end{array}$

$\begin{array}{ll}\text { Substantive Values } & 14\end{array}$

$\begin{array}{ll}\text { Procedural Values } & 16\end{array}$

Key Considerations + Implications $\quad 18$

$\begin{array}{ll}\text { Moving Forward } & 21\end{array}$

$\begin{array}{ll}\text { References } & 22\end{array}$ 


\section{LIST OF FIGURES}

\begin{tabular}{|c|c|c|}
\hline Figures & & Page \\
\hline 1. & $\begin{array}{l}\text { The canoe route from Lansdowne House to Summer Beaver is } \\
\text { approximately ninety-seven miles and thirty portages............... }\end{array}$ & 5 \\
\hline 2. & $\begin{array}{l}\text { Map of Ongoing Community Based Land Use Planning in the Far North } \\
\text { of Ontario as of July } 25,2014 \ldots \ldots \ldots \ldots \ldots \ldots \ldots \ldots \ldots \ldots \ldots \ldots \ldots \ldots \ldots \ldots \ldots \ldots \ldots \ldots \ldots \ldots \ldots \ldots\end{array}$ & 8 \\
\hline 3. & 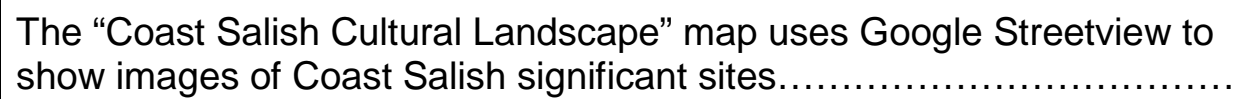 & 18 \\
\hline
\end{tabular}




\section{Executive Summary}

\section{Project Summary}

Through a partnership between Nibinamik First Nation and Ryerson University, this project is part of a long-term mapping and community land use planning project. Since Fall 2017, community stakeholders from Nibinamik met with the Ryerson team to discuss the goals, vision, and values for a mapping project that will support an update of the existing land use plan. This project also involved a review of the literature on Indigenous "counter-mapping" and of the guiding planning policy framework.

Following Minkin et al (2014), the values identified by community stakeholders were categorized into the following groups:

1. Substantive values: the content of the maps themselves; and

2. Procedural values: the process and methods of mapping, the objectives for mapping, and the scope of the project.

The following substantive values were identified:

- Environmentally sensitive areas

- Travel routes

- Hunting and trapping

- Historic and sacred sites

- Areas for reserve expansion

- Potential for economic development

- Family camps and recreation

- Shared territories

The following procedural values were identified:

- Decision-making and engagement

- Knowledge transfer and tradition

- Scoping: inclusion of other communities

- Self-determination and renegotiation of power

Key considerations of these values are summarized in a summary table, below.

The values and considerations identified in this project provide a guiding framework for the longterm goals of Nibinamik's mapping and land use planning project. Findings of this project also highlight key implications for provincial policy and identify sources of conflictual values between Nibinamik and the province, especially with respect to power and partnership. 
Summary Table: Values and Considerations

\begin{tabular}{|c|c|}
\hline Values & Key Considerations \\
\hline \multicolumn{2}{|l|}{ Substantive Values } \\
\hline $\begin{array}{l}\text { Environmentally Sensitive } \\
\text { Areas }\end{array}$ & $\begin{array}{l}\text { Land use and occupancy (LUO) mapping is an appropriate method } \\
\text { for recording environmentally sensitive areas, including animal } \\
\text { nesting areas. } \\
\text { LUO can be limited in its ability to collect and record changes in the } \\
\text { environment over long periods of time. } \\
\text { A policy for access to and distribution of this knowledge should be } \\
\text { considered. } \\
\text { It is important for all community members to be consulted in the } \\
\text { identification of environmentally sensitive areas. }\end{array}$ \\
\hline Travel Routes & $\begin{array}{l}\text { Travel routes can be recorded through participatory mapping } \\
\text { processes, and can provide an opportunity for youth and other } \\
\text { community members to experience culturally significant travel } \\
\text { routes, such as the trip from Lansdown House to Nibinamik. } \\
\text { There are methods of cybercartography that use GPS units to } \\
\text { record travel routes, which can be very expensive. } \\
\text { A policy for access to and distribution of this knowledge should be } \\
\text { considered. }\end{array}$ \\
\hline Hunting and Trapping & $\begin{array}{l}\text { It was identified that consultation for hunting and trapping areas } \\
\text { should be done according to the five original family groups that } \\
\text { came to Nibinamik. Nibinamik should consider developing a formal } \\
\text { process for this consultation strategy that is approved by the } \\
\text { community, to ensure fair representation and to avoid conflicts. } \\
\text { A policy for access to and distribution of this knowledge should be } \\
\text { considered. }\end{array}$ \\
\hline Historic and Sacred Sites & $\begin{array}{l}\text { Interactive mapping technology, that allows for multimedia } \\
\text { attachments, is recommended to balance the demands for recording } \\
\text { both land use and cultural significance. } \\
\text { Mapping these areas, and compiling multimedia attachments, is an } \\
\text { opportunity to engage youth and for intergenerational sharing. } \\
\text { Training for collecting, editing, and maintaining an interactive } \\
\text { system will be required. } \\
\text { A policy for access to and distribution of this knowledge should be } \\
\text { considered. }\end{array}$ \\
\hline $\begin{array}{l}\text { Areas for } \\
\text { Residential/Reserve } \\
\text { Expansion }\end{array}$ & $\begin{array}{l}\text { Planning for the future needs of the community should be done in } \\
\text { consultation with the community to identify key priorities and a vision } \\
\text { for the future. }\end{array}$ \\
\hline $\begin{array}{l}\text { Potential for Economic } \\
\text { Development }\end{array}$ & $\begin{array}{l}\text { The desire to promote economic development was discussed in } \\
\text { relationship to protecting and sustaining the traditional way of life. } \\
\text { A policy for access to and distribution of this knowledge should be }\end{array}$ \\
\hline
\end{tabular}




\begin{tabular}{|c|c|}
\hline & considered. \\
\hline $\begin{array}{l}\text { Family Camps and } \\
\text { Recreation }\end{array}$ & $\begin{array}{l}\text { Identification of family camps and recreational areas can be done as } \\
\text { part of a community consultation strategy. } \\
\text { A policy for access to and distribution of this knowledge should be } \\
\text { considered. }\end{array}$ \\
\hline Shared Territories & $\begin{array}{l}\text { Mapping shared territories should be done in consultation with other } \\
\text { communities. } \\
\text { A policy for access to and distribution of this knowledge should be } \\
\text { considered, especially because of the potential for } \\
\text { misunderstandings with the province and conflict. }\end{array}$ \\
\hline \multicolumn{2}{|l|}{ Procedural Values } \\
\hline $\begin{array}{l}\text { Decision-making and } \\
\text { Engagement }\end{array}$ & $\begin{array}{l}\text { Community-wide participation and approval is encouraged for this } \\
\text { project. The knowledge and goals of the community can only be } \\
\text { captured through engaging the community in all levels of the project. } \\
\text { The inclusion of women, children, and } 2 S Q \text { community members is } \\
\text { especially important, through a decolonial lens. } \\
\text { Mapping technologies should be selected based on their } \\
\text { accessibility to community members. }\end{array}$ \\
\hline $\begin{array}{l}\text { Knowledge Transfer and } \\
\text { Tradition }\end{array}$ & $\begin{array}{l}\text { The project is an opportunity to bring together the knowledge of the } \\
\text { community and preserve that knowledge for future generations. } \\
\text { Working with the school is one way to involve youth, and encourage } \\
\text { the mapping project to be part of curriculum development. }\end{array}$ \\
\hline $\begin{array}{l}\text { Scoping: Inclusion of } \\
\text { Other Communities }\end{array}$ & $\begin{array}{l}\text { A consultation strategy should be developed, in consultation with } \\
\text { the community of Nibinamik, to identify and reach out to other } \\
\text { communities for involvement. } \\
\text { If there is a strong desire to share the maps with other communities, } \\
\text { or collaborate on them, mapping technologies should be selected } \\
\text { based on ease of sharing. }\end{array}$ \\
\hline $\begin{array}{l}\text { Self-determination and } \\
\text { Renegotiation of Power }\end{array}$ & $\begin{array}{l}\text { The mapping and land use planning project should be discussed } \\
\text { with Nibinamik's legal council to ensure that the project can support } \\
\text { long term goals for partnership and nation-to-nation relations with } \\
\text { the province. }\end{array}$ \\
\hline
\end{tabular}




\section{Background}

Nibinamik First Nation, also known as Summer Beaver, is an Anishinaabe community located in northern Ontario, approximately 500 kilometres north of Thunder Bay. The ancestry of the people of Nibinamik can be traced back to Northern Ojibwa Communities that comprised of camps along the shores of Lake Superior and surrounding rivers (Driben \& Trudeau, 1983). The territory for these Anishinaabe families could cover large stretches of land or smaller areas and the predominant way of life, 'a-da-waa-gee-gay-win', centred on living off the land and seeking game (Driben \& Trudeau, 1983). The first contact between the Fort Hope band and european missionaries and trappers occured in the early 1600s. The fur trade occurred in this region into the 1700s when missionaries began to have an impact on traditional practices. By the early 1800s, increased pressure on wildlife due to over hunting and trapping encouraged First Nations to move closer to trading posts for better quality of life (Coates, 2015). Starvation and disease played a major role in movement away from the traditional way of life, toward government assistance available at larger community hubs. This brought people from a number of different families together.

Upon recognition of the economic potential for resource exploitation and development in the near-north of Ontario in the early 1900's, a treaty was pursued (Gardner et al, 2010). The terms of the treaty were negotiated between the Government of Canada and the Government of Ontario prior to attaining First Nations approval (Gardner et al, 2010). Historians and First Nations leaders maintain that the Treaty process failed to properly consult and negotiate with First Nations (Gardner et al, 2010). The Treaty, for example, was only written in English, and the commissioners did not travel with translators (Gardner et al, 2010). Treaty 9 was signed by various First Nations in 1905 and 1906. Through the eyes of the state legal system, the signing of the treaty meant the Fort Hope people and other First Nations in Treaty 9 territory signed over their rights to the land in exchange for hunting, trapping, and fishing rights subject to regulation, education, a yearly cash "present", and reserve lands (Gardner et al, 2010; Long, 2006). Community members of Nibinamik maintain that the Fort Hope peoples signed the treaty without proper understanding of its terms. Although reserve lands occupy a relatively small amount of space, "...the areas historically and currently used for traditional activities by First Nations peoples are vast. Ownership of these lands has been claimed both by provinces that define them as 'Crown' land and by First Nations that define them as 'traditional territories'." (Smith, 2015). The dichotomous interpretation of treaty rights, which posits shared power against exclusive State power, remains unresolved. 
The post-treaty time brought more change for the Fort Hope band, some of whom now resided in Lansdowne House. Residential schools, amongst other colonial policies, and religious conflicts within the community brought challenges and strife to the Fort Hope Band people. In the summer of 1975, five families residing in Lansdowne house decided to leave:

"Things happened in Lansdowne that's why they moved because of alcoholism, sniffing gas, solvent abuse. All those things. That's why they came here" (Nibinamik Elder quoted in Ineese-Nash, 2016).

Approximately ninety people left Lansdowne House in order to establish a new community in a traditional gathering area: Nibinamik. After the long journey there, the people began to build the community without government assistance. Today, Nibinamik is home to approximately 380 community members. For many community members, the legacy of determination and vision that founded their community is a source of pride and strength (Ineese-Nash, 2016).

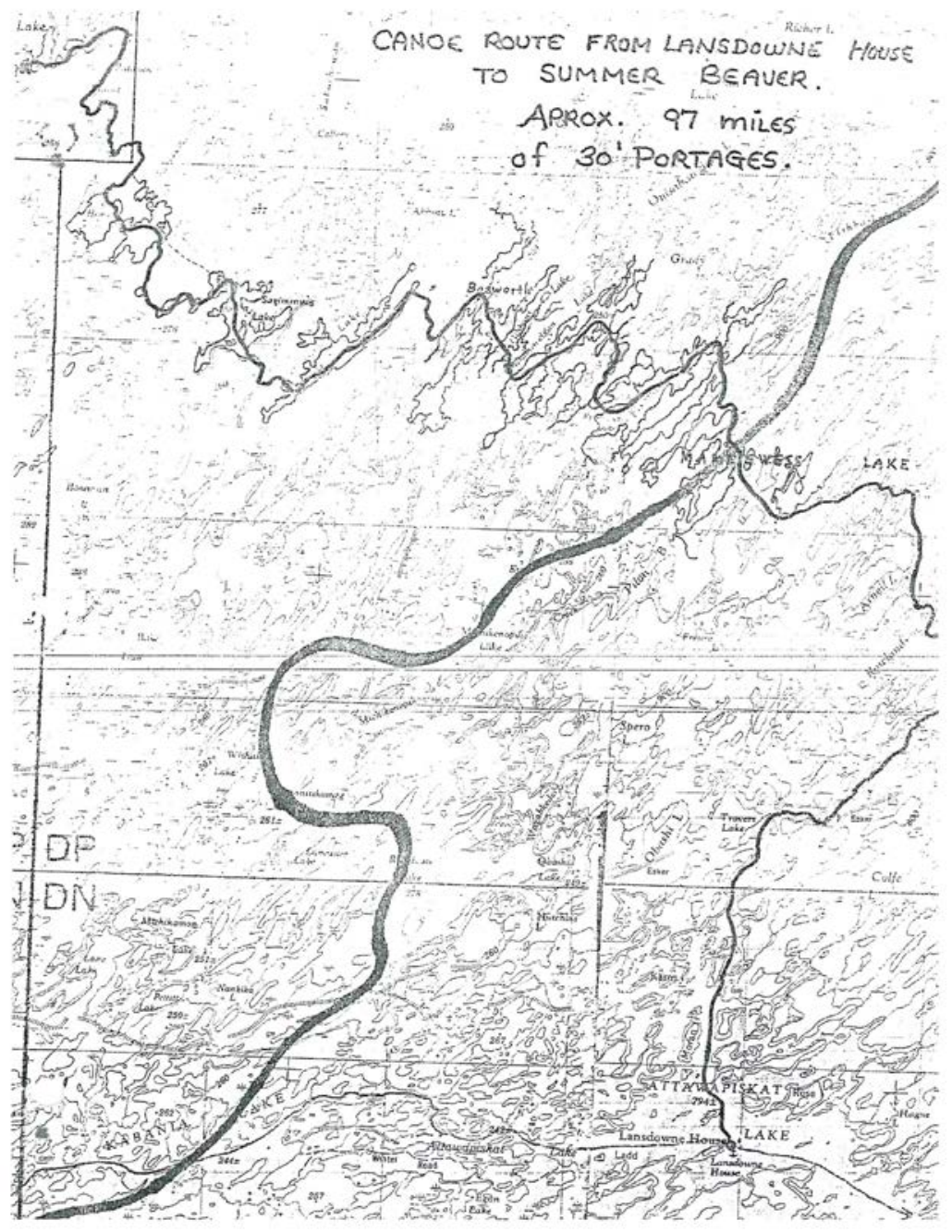

Figure 1. The canoe route from Lansdowne House to Summer Beaver is approximately ninety-seven miles and thirty portages (Obtained from Nibinamik Lands Office). 


\section{Policy Context}

In 1979, the elected band council of Nibinamik launched their proposed Land Use Plan (LUP), which has subsequently been updated in 1983. The LUP outlines the parameters of Nibinamik's traditional territory, develops strategies to address community concerns, and plans for the future of the community. Nibinamik is in the process of updating the LUP. Central to this process is the desire to map the knowledge that will inform and support the plan, and the provincial planning policy that informs and constrains this work. Nibinamik's LUP and mapping project is operating within the context of Ontario's relatively new Far North Land Use Planning Initiative. Whereas the near-north of Ontario has faced many changes due to development, Ontario's Far North is relatively untouched (McCarthy et al., 2012). In 2007, the Ring of Fire, a large area for chromite mining in northern Ontario, comparable in economic impact to the Alberta tar sands, was discovered (Sudol, 2014). In preparation for development in this area, the province developed the Far North Land Use Planning Initiative.

The Far North is an area that covers forty-two percent of Ontario's land mass and stretches from Manitoba in the west, and Quebec in the east (Ontario Ministry of Natural Resources and Forestry, 2012). The area is home to 24000 people, ninety percent of whom are First Nations (ibid). Additionally, the area is home to a number of sensitive species, and two regions important for carbon sequestration: the boreal forest of the Canadian Shield and the bogs and fens of the Hudson Bay Lowlands (ibid). For the province, the Ontario Far North Land Use Planning Initiative " ... is about working with First Nations to identify where development can occur and where land is dedicated to protection in the Far North of Ontario" (Ontario Ministry of Natural Resources and Forestry, 2015). There are three main elements of this Initiative: community based land use planning with First Nations, set out in the Far North Act (2010); developing the Far North Land Use Strategy; and science and information to support planning (ibid).

The Far North Act is the legislative foundation for land use planning in the Far North, and is arguably the most significant piece of planning legislature passed by the province in decades (Minkin et al., 2014). The purpose for the Act, set out in Section 1, is to: set out provisions for a joint planning process between First Nations and the province; support environmental, social, and economic objectives for the Act; and to uphold Aboriginal Treaty Rights and Section 35 of the Constitution Act (1982), including the duty to consult (Ontario Ministry of Natural Resources and Forestry, 2010). The objectives for land use planning set out in Section 5 of the Act are:

1. A significant role for First Nations in the planning [emphasis added]; 
2. The protection of areas of cultural value in the Far North and the protection of ecological systems in the Far North by including at least 225,000 square kilometres of the Far North in an interconnected network of protected areas designated in community based land use plans.

3. The maintenance of biological diversity, ecological processes and ecological functions, including the storage and sequestration of carbon in the Far North.

4. Enabling sustainable economic development that benefits the First Nations. (Ontario Ministry of Natural Resources and Forestry, 2010)

Although the Act aims for a significant role for First Nations in the planning process, it ultimately restricts First Nations to local land-use planning that is subject to the goals of the Act and ultimate approval of the Minister (ibid; Smith, 2015).

The Act raised many concerns for First Nations. These concerns include: "inadequate consultation; negative impacts from land use planning on treaty and indigenous rights; jurisdictional separation of FN traditional territories; inadequate resourcing; and limited power sharing" (McCarthy et al, 2012). The Assembly of First Nations (AFN) supported NAN's call for the province to withdraw the Act:

"Consistent with our rights, the treaties and the United Nations Declaration on the rights of Indigenous Peoples, First Nations must be fully and meaningfully engaged in all aspects relating to development in our territories. The Ontario government's approach to the proposed Far North Act is inconsistent with First Nation rights and the treaties and furthermore does not adequately fulfill the government's duty to consult. Especially in regions like Northern Ontario where First Nations peoples make up 90 per cent of the population, it is absolutely essential that we get this right. The path forward must be one of full respect and engagement." (Shawn Atleo, Former National Chief of AFN, quoted in Canada Newswire, 2010)

Dichotomous interpretations of treaty rights are present in both the province's declaration of exclusive power over Crown lands, and First Nations' assertion of shared power over their traditional territories. This informs the 'unsteady footing from which planning proceeds in the province' (Beger et al, 2010 quoted in Smith, 2015). In this way, the Act holds a tremendous amount of potential for conflict (Minkin et al, 2014).

The province did not withdraw the Act, and many First Nations have created, or are in the process of creating, community land use plans (CLUP) under the Act. Upon initiation of a CLUP, some First Nations have dropped out of the process. When First Nations do not engage in CLUP with the province, the province maintains land use planning authority over lands (Ontario Ministry of Natural Resources and Forestry, 2010). Rather than complete a CLUP with the province, Nibinamik First Nation seeks a self-determined approach to land use planning for their traditional territory. As part of this process, Nibinamik seeks to (re)map their traditional territory according to local knowledge, process, and jurisdiction. 


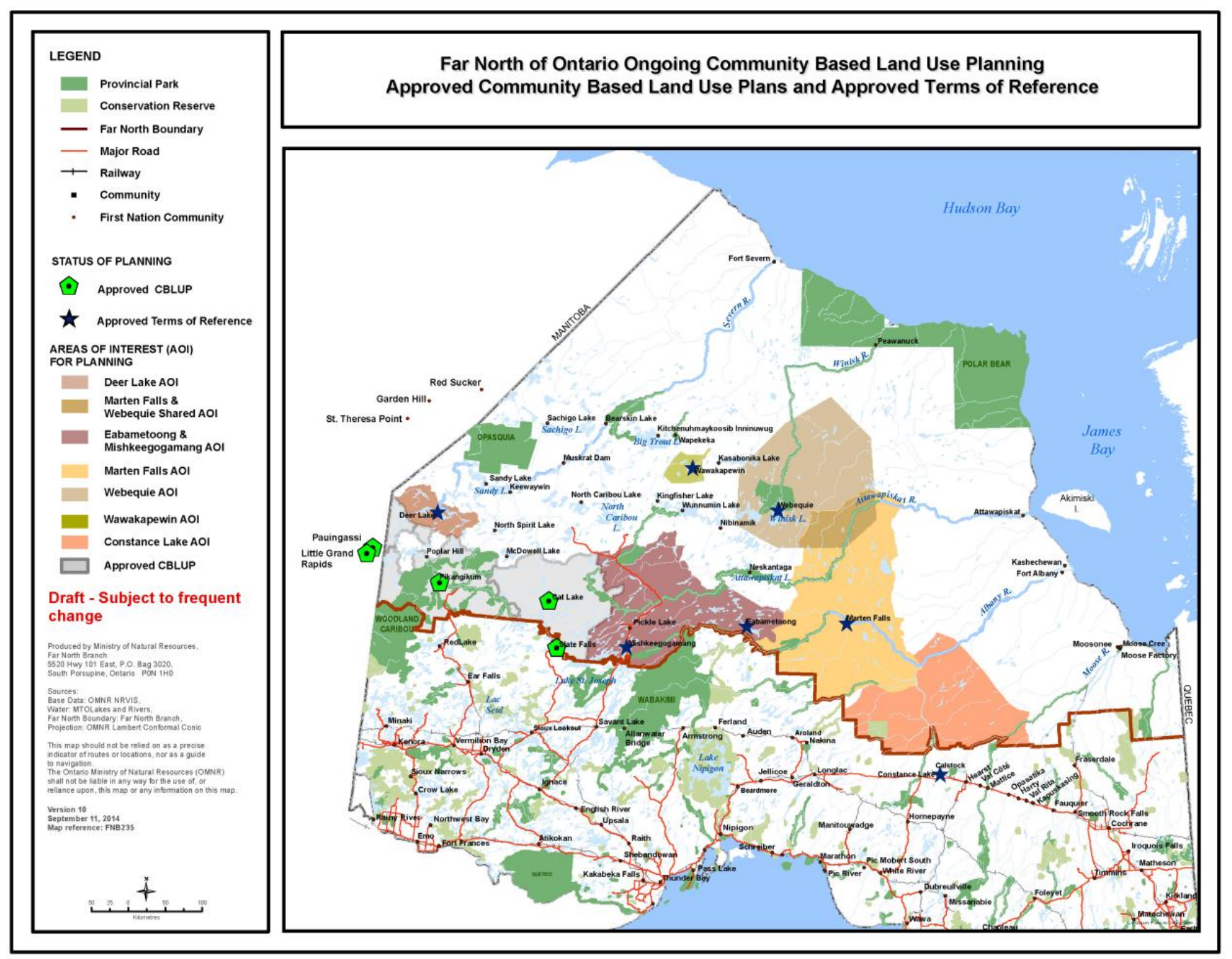

Figure 2. Map of Ongoing Community Based Land Use Planning in the Far North of Ontario as of July 25, 2014 (Ministry of Natural Resources and Forestry, 2014). 


\section{Maps and Power}

Maps as a Tool of Empire

Critical Cartography holds that maps have power and are comprised of many claims, truths, and ways of seeing (Wood, 1992). The information provided on a map, and how it is represented, tells a story (Harley, 1989; Wood, 1992). All aspects of the map are, therefore important for this storytelling process. Through these stories, maps not only represent the world, they create it (Wood, 1992). In this way, maps must be considered in the context of the political, cultural, and social subjectivities that shape them (Cidell, 2008; Wood 1992; Crampton 2010). In particular, critical cartography encourages one to look beyond the "taken-for-grantedness" of maps, and to engage in a process of unveiling the power dynamics behind their construction (Wood 1992; Pickles 1995; Crampton 2009). This perspective calls for a second look at "mapping as scientific process", a view highly influential on modern mapping and GIS, toward an understanding of the systems of power that shape representation, often to the detriment of local knowledge (Pickles, 1995).

For the purposes of colonization, maps are a tool of empire (Goeman, 2013; Tobias, 2009). The period of European Enlightenment defined culture as European society (Johnston \& Murton, 2007). Drawing clear dichotomies between culture and nature enabled the "colonial construction of Nature" (Johnston \& Murton, 2007), whereby Native voices were aligned with the natural, wild world, not with culture and civilization (Miller, 2010). Through this lens, the Doctrine of Discovery deemed Indigenous people as unfit to govern land. This "rationalism of racism" was used to justify the seizure of land from Indigenous peoples, framing lands of the "new world" as free for the taking and established "....an insidious discourse of dominance [that] hides in the idea that the nation-state's rights trump the rights of the Indigenous nations residing within" (Shanley, 2015, p 17). The mapping of land in settler societies is, therefore, intrinsically linked to the process of identifying Indigenous people as inferior (Shanley, 2015). The surveying of lands and resources still takes place in Canada's resource-driven economy, and continues to play a role in solidifying normative views of the land and Indigenous peoples (Hunt \& Stevenson, 2017).

The term colonial spatializing refers to the "nationalist discourses that ensconce a social and cultural sphere, stake a claim to people, and territorialize the physical landscape by manufacturing categories and separating land from people" (Goeman, 2008, p 296). Through this process, "progress" is seen as the integration of Indigenous peoples, and defining spaces of wilderness away from areas inhabited by humans (Shanley 2015). Wilderness is managed for 
spaces of recreation or for capitalization (Shanley 2015). Reserves themselves are tracts of land set aside for the "use and benefit" of Indigenous people. The dichotomy of "on-rez" and "off-rez" are Western paradigms that have been imposed on Indigenous people in order to remove them from traditional ways of being and knowing (Goeman, 2013). These forced dichotomies shape not only the physical, but also the mental and emotional ways of experiencing and defining place (Goeman 2008; Goeman, 2013). The reordering of space via the process of colonization brought disorder to Indigenous people, disrupting communities and ways of being (Hunt, 2017; Goeman, 2013). This presents “...a narrative wherein settlers become great "pioneers," and Indigenous people ghosts" (Hunt, 2016). The colonial legacies behind maps is lost by their presentation as neutral or objective truths. This opens up space for remapping on other terms, and the "decolonizing potential" of Indigenous counter-mapping (Hunt \& Stevenson, 2017).

Indigenous Counter-Mapping

Over the past few decades, there has been a lot of work re-mapping Indigenous lands (Wainwright \& Bryan, 2009). This practice is often referred to as counter-mapping, a process of mapping that challenges dominant portrayals of land and space. (Re)defining territory is a central theme in Indigenous counter-mapping and in 'the modern treaty era', defining space through mapping contested territories is central to the Indigenous rights movement (Hunt \& Stevenson, 2017). The documentation of territory and resources through various countermapping approaches allows Indigenous communities to exercise sovereignty within dominant structures of environmental governance (Olsen et al, 2016; Sletto, 2009). Counter-mapping can “...destabilize dominant hegemonic narratives by extending the representation of space beyond the empty orthogonal, aerial perspectives provided by state and industry, to detail and visualize Indigenous socio-spatial relationships" (Olsen et al, 2016).

Land use and occupancy (LUO) mapping is a prominently used form of countermapping, stemming from land claims negotiations undertaken by the Inuit (see Freeman, 2011), during the 1970's (Tobias, 2009). While there are variations in the names of these maps, they have two common features: data collection is based in a map-biography method; and the maps document evidence of Indigenous use and occupancy of the land (Tobias, 2009). Use refers to the harvesting of resources, whereas occupancy refers to a group's traditional ownership or control over the lands (ibid). The map biography method is “....an account of a person's life on the land, sea, or ice, as recorded on a map (and audio recording) during a face-to-face interview" (Tobias, 2009, pg 38). Advancements in technology create new opportunities for 
Indigenous LUO mapping. A cybercartography approach (Taylor, 2005) “... is the organization, presentation, analysis and communication of spatially referenced information on a wide variety of topics of interest and use to society in an interactive, dynamic, multimedia, multisensory and multidisciplinary format" (Scassa et al, 2015). It is a method used by Indigenous communities to collect and curate traditional knowledge and culture, from language to hunting trails (ie Aporta, 2011; Caquard et al, 2009; Gearheard et al, 2011). A major benefit of the cybercartographic approach is its ability to capture qualitative aspects of traditional knowledge, for example through photos and storytelling, and its ability to preserve information (Scassa et al, 2015). An increased reliance on LUP mapping, using various technological approaches, highlights the need to examine LUO critically.

Olsen et al (2016) argue that in the age of increased reliance on LUO mapping, it is important for Indigenous communities to develop standards for the control of their information and quality indicators for new methods and technologies entering the field. Additionally, LUO maps do not always take into account long-term cycles that influence resources (Natcher 2001b cited in Minkin, 2014). LUO mapping processes can exclude certain voices, including women's voices, and, the heavy reliance on the physical landscape does not always capture cultural values (ibid). An ethnographic approach can mitigate these effects through examination of the cultural values related to mapping projects (i.e Ethnographic Mapping Lab, 2018).

Indigenous ways of mapping are not only literal or geographic spaces, but also consist of mental, emotional, and spiritual pathways and planes that are passed down from generation to generation (Shanley, 2007). Space is not only territory, but also relationships, place, and belonging. Spatial separation from tribal communities and incorporation into the nation-state were primary goals of the assimilationist agenda, the re-ordering of Indigenous spaces (Goeman, 2008). Storytelling is a way to convey complex relationships between place, landscape, clan systems, Indigenous people (Goeman, 2008, pg 300). Stories are a critical part of Indigenous culture that "serve as fertile grounds wherein the layers of geography are unfolded, exploited, and expounded upon" (Goeman, 2008). Conflicts between the mapping of Western scientific knowledge and local knowledge reveals the social construction of western scientific knowledge in a way that can challenge its assumed legitimacy (Cidell, 2008), or, as Goeman asserts, "unbury the roots of spatial colonization and lay bare its concealed systems" (Goeman, 2008, p 295). Here, the power of maps lies in the ability to turn imagination into reality, and storytelling is a strategy for reimagining the layers of power in present day maps (Goeman, 2013). 
Despite movement toward Indigenous counter-mapping, there remains a tendency to view Western cartography as the standard against which to measure other forms of cartography (Louis, 2012). "Cartographic encounters" are the interaction between modern and Indigenous cartographies where Indigenous cartographies are placed on the sidelines (Louis, 2012). Indigenous cartographies are often relegated to the past, as if they can no longer exist in a modern context (Louis, 2012). In this way, counter-mapping is criticized for appropriating Western techniques and representations in order to "bolster legitimacy" (Louis, 2012). Louis defines "geographic translation", as a process of communication between one cultural set of measurements to another. This process raises its own set of challenges including, mistranslation and misrepresentation, that may go unaddressed in counter-mapping (Louis, 2012). Mapping of territory, for example, can be problematic in its appropriation of Western notions of territory (Thom, 2009; Sletto, 2009), that are used primarily to define terra incognita, or blank space (Goeman, 2013). Jurisdiction over territory also varies. While settler authority over land comes from colonial and imperial legacies, Indigenous jurisdiction comes from a different set of legal traditions (Pasternak, 2017). Geographic translation of these concepts is a challenge of Indigenous counter-mapping. LUO mapping and cybercartography are criticized for not engaging in the debate on the incorporation of Indigenous knowledge (IK) into positivist frameworks (Hunt \& Stevenson, 2017; Olsen et al, 2015; Scassa et al, 2015):

"Due to being situated within Western-based cartographic representations of space, the map biography method suffers from the problematic effects of documenting and visualizing IK and oral tradition within Western-based cartographic methods and tools. As a result, the process reiterates and reworks residual power asymmetries, requiring Indigenous communities to eschew epistemic and ontic knowledges for statist spatial data obligations. Yet, because of existing constraints that underpin legal and regulatory requirements, the use of spatial data quality, rooted in Western-based representations of space, manifests the necessary visual and credible base to engage with the 'technicallegal valences' required by legal and regulatory institutions" (Olsen et al, 2015).

Hunt \& Stevenson refer to this as the "double bind" of Indigenous counter-mapping (2017). Another key consideration is that cartographic discourse is powerful and grounded in modern relations and policy. For this reason, power may not easily be disrupted via counter-mapping (Hunt \& Stevenson, 2017). 


\section{Project Approach}

This project was conducted through a series of meetings with stakeholders from the Nibinamik Band Office and Lands Office that took place from October 2017 to February 2018. These meetings took place during stakeholder visits to Toronto and during two week-long site visits to Nibinamik, one in October 2017 and one in February 2018. Initial meetings in Fall 2017 aimed at scoping this project, and identifying key values and goals informing the long-term mapping and land use projects. Concurrently, a review of grey and academic literature identified key themes related to Indigenous counter-mapping and land use planning in the Far North. In particular, secondary research aimed to: provide examples of the types of mapping projects being undertaken by other Indigenous communities; understand strengths and challenges of various approaches to counter-mapping; understand the relationship between maps and the control of land and resources, especially in the Far North. Stakeholders from the Land's Office requested a presentation of findings to date, and, during the February site visit this was done at a meeting that brought together a group of local stakeholders. Local priorities and values were discussed and evaluated in relation to the major findings of secondary research.

This project operates through the theoretical framework of Indigenous Planning Theory. Indigenous Planning Theory holds that Indigenous Planning requires a community-based, grassroots approach that is informed by a locally determined process and systems of knowledge (Natcher, Walker, \& Jojola, 2013). This grassroots approach upholds principles of self-determination and decolonization by prioritizing local jurisdiction over state recognition (Natcher et al, 2013). This project approaches the discussion of Nibinamik's mapping and land use planning project through the lens of Indigenous Planning Theory. 


\section{Substantive and Procedural Values}

The values informing Nibinamik's LUP and mapping project are crucial to identify as they will inform key decisions in how the map will be created and what it will look like. Addressing concerns about the heavy reliance of LUO mapping on harvesting and physical landscape, this project seeks to evaluate a range of values underpinning Nibinamik's desire to engage in counter-mapping, prior to identifying the tools and processes best suited to uphold and reflect local values. Following Minkin, Whitelaw, McCarthy and Tsuji's work to identify the values informing Fort Albany First Nation's community land use planning initiative (2014), Nibinamik's values for the mapping project have been categorized into substantive and procedural values. Substantive values are related to the content of the maps themselves (Minkin et al, 2014). Procedural values are related to the process and methods of mapping, the objectives for mapping, and the scope of the project (Minkin et al, 2014). The following discussion will identify Nibinamik's substantive and procedural values for undertaking this counter-mapping project. Where appropriate, sub-categories are in keeping with Minkin et al's classification (2014).

\section{Substantive Values}

\section{Environmentally Sensitive Areas}

Environmentally sensitive areas were identified as necessary to include in this mapping project. Areas significant for wildlife, such as animal nesting areas, were noted as important to map so that they are not disturbed with development. Preservation of environmentally sensitive regions is an important value expressed for this project.

\section{Travel Routes}

Travel routes, both historic and current were identified as important to include on the map. Travel routes including waterways, snowmobile trails, winter roads, and a proposed allyear road came up as important to document on the map. Some community members expressed the importance of documenting historically significant travel routes that hold additional cultural meaning for the community. It was also pointed out that the travel routes used decades ago, are now becoming overgrown due to underuse. One stakeholder mentioned that the places he used to go with his father and grandfather are all in his mind, and that they should be recorded so that they are not lost with him.

\section{Hunting and Trapping}

Mapping of hunting and trapping areas was identified as an important map feature. These areas are considered important for recording so that this information can be shared with the province, and to ensure that these areas are protected from development. It was noted that 
trapping areas should be recorded according to family groups, and not according to provincial trapline records.

\section{Historic and Sacred Sites + Place Names}

The mapping of historic and sacred sites was expressed as a very important layer of information. One community leader expressed that the historic and sacred sites should be one of the first layers to work on, citing a recent conflict with outsiders. Outsiders came into the traditional territory for recreational hunting and were found camped out near a burial site. One community stakeholder suggested that if there was a map of these significant sites, conflicts like this could be avoided. In addition to preventing conflicts, mapping of these sites was also seen as a way to preserve these important areas in the face of colonial erasure.

\section{Areas for residential/reserve expansion}

To inform future land use planning for the reserve area, areas for reserve expansion were discussed as important areas to identify and record. These areas would include zoning for new residential areas, and planning for the future needs for the community.

\section{Potential for Economic Development}

Areas for potential economic development were identified as an important feature to map. Ecotourism is viewed as an important area for potential economic development, including the mapping of areas for visitors to access. Having maps available for such activities was discussed as one way to promote and control eco-tourism activities. Other areas of economic development activities discussed include forestry and mining.

\section{Family Camps and Recreation}

Going "into the bush" was identified as an important part of life for community members. Many families have camps on the land that are used for going out in the bush. These camps, and other areas for recreation, were identified as important to be recorded in the mapping process.

\section{Shared territories}

The edges of Nibinamik's traditional territory were discussed in relation to bordering First Nations. Community stakeholders identified the need to address any overlap with bordering First Nations, not only with respect to potential development impact on bordering lands, but also because of frequent traditional travel between territories. Stories were shared of travelling widely across Treaty 9 territory to access various resources, with agreements made or notice given for travelling and harvesting. Community stakeholders also discussed kinship networks that connect people across territorial boundaries. 
Procedural Values

Procedural values are as follows:

Decision-making and Engagement

Community members identified the need for the whole community to be involved in the mapping process through both consultation and engagement. One stakeholder mentioned that there is already so much knowledge in the community, and mapping could be a way to draw this knowledge out. One Elder explicitly mentioned the importance of including women's knowledge, noting that women are historically excluded from provincial trapline mapping. Additionally, it was stated that consultation for the mapping project should be done according to the five original family groups of Nibinamik, not according to state regulated traplines. The importance of consulting with families was reiterated by other stakeholders, not only for accuracy and knowledge, but also as a way of bringing people together. Youth were mentioned as an especially important group to be engaged in the process.

Stakeholders agreed that community members of Nibinamik should be trained to take on the majority of the mapping work and be able to conduct maintenance. The level of community engagement desired for the scoping of the project and decision making varied across stakeholders. Whereas one community stakeholder believed a community-wide meeting was required to scope and phase the project, others believed these decisions were better left to a small group of community members with experience in land management.

Knowledge transfer + Tradition

The mapping project was identified as a potential tool for cultural preservation and revitalization through knowledge transfer and education. Community stakeholders noted the intergenerational disruption in the transmission of important cultural knowledge in their community. Mapping historic and sacred sites was discussed as especially beneficial for local youth. One community member shared that they believe the community's suicide crisis is related to youth not knowing who they are. Having maps that can show youth where they come from and who youth are as a people is believed to have tremendous benefits for youth, and for the community at large. One stakeholder suggested that the maps could be used as part of a "way of life" curriculum in the school. In this way, the maps are discussed as a sort of archive. Bringing youth and elders together in a mapping process was identified as a way to overcome intergenerational divides, and preserve knowledge and language. This would also open up opportunity for experiential learning through the mapping process.

Community stakeholders noted the importance of maps being accessible to the community. The use of interactive and multimedia features was seen to be an appropriate way 
to ensure accessibility and proper transmission of cultural knowledge. Local maintenance and updates were also identified as important.

Scoping: Inclusion of Other Communities

It was noted that bordering First Nations should be included in the process because:

there is a lot of shared history; they have overlapping territories; and traditional travel and hunting took place across territories. In this way, inclusion of other First Nations is seen not only as important for accuracy and shared jurisdiction, but also as a way of connecting to broken kinship networks. To this end it was mentioned that there should be regional consultation and sharing, beyond bordering territories. One community stakeholder described this as a was of "reconnecting to a way of life" and showing that First Nations communities are connected.

\section{Self-determination + Re-negotiaton of Power}

The act of mapping and planning for the traditional territory independently from the province was described by an Elder as a way to "declare the land". The values informing the process reject the state's claims of exclusive power over the land. Community stakeholders believe that they know how to manage the lands, and it is not appropriate for this project to take place under the supervision of the province. At the end of the day, stakeholders do hope that the province will recognize their plan, but the self-determined approach repositions power away from the top-down policy framework imposed by the Far North Act. One community stakeholder mentioned that they want to work in partnership with the province and that they hope this project can be part of a permanent change in provincial relations, toward nation-to-nation recognition. 


\section{Key Considerations + Implications}

Contrary to the "conservationist indian" myth (Smith, 2015), the findings suggest that Nibinamik seeks to balance sustainable economic development with cultural preservation and revitalization. The desire to map historic and sacred sites, travel routes, hunting and trapping, and areas for economic development suggests that a strict LUO approach would be limiting, and may be balanced with ethnographic mapping techniques that considers representation of space, land, and values. The use of multimedia data collection, such as videos and voice recorders, can be used to balance western cartographic approaches with more authentic representations of local systems of knowledge (i.e Ethnographic Mapping Lab, 2018).

Values around community engagement, access, and maintenance will be best upheld through participatory mapping processes and a strategic approach to community engagement. This can help to ensure a true grassroots approach to knowledge development, and avoid replication of biased mapping processes that privilege certain voices over others. Technological choices can be made with accessibility at the front of mind, which may prioritize basic technologies such as Google Earth, over complicated GIS technology (Corbett, 2009). Although internet access is limited, there is precedent for use of google earth technologies in "remote" areas (Thom et al, 2016).

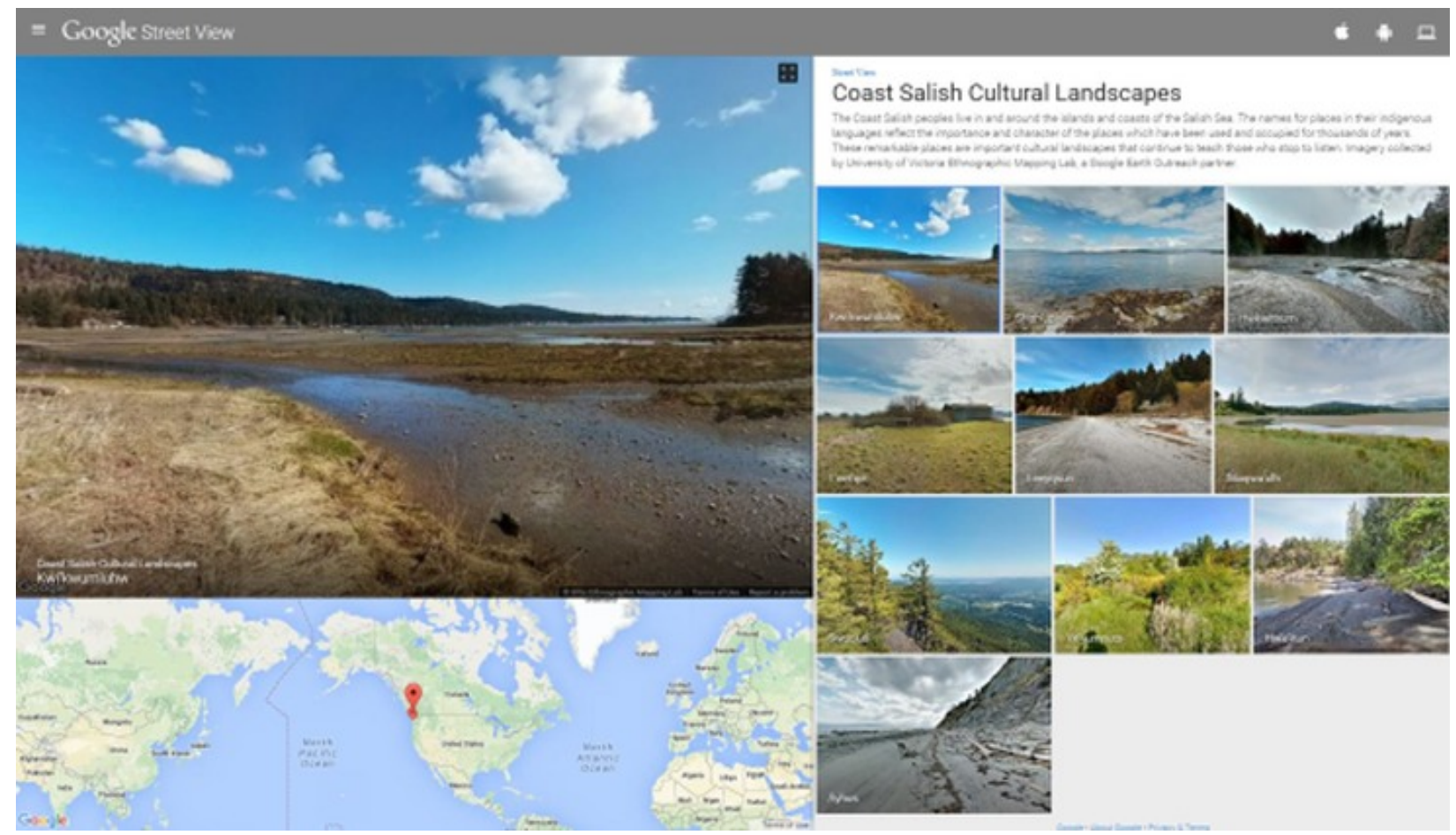

Figure 3. The "Coast Salish Cultural Landscape" map uses Google Streetview to show images of Coast Salish significant sites (Ethnographic Mapping Lab, 2018). 
Knowledge sharing is an important consideration for this project. Nibinamik identified the desire to share data with other First Nations. Online mapping and data bases, such as Web Informatics Development Environment (WIDE) (see McCarthy et al, 2014), can be explored to this end. Privacy is an additional concern, especially in light of values around self-determination and renegotiation of power. Nibinamik must consider what, and how much, knowledge will be shared with the province, and other outsiders. Given the province's track record of consultation and negotiation with First Nations in the Far North (see Garner et al, 2008), Nibinamik should consider an approach that promotes consultation for all decisions made that impact their traditional territory. Through the CLUP process, for example, the province allows First Nations to withhold traditional ecological knowledge collected through shared planning process. In order to uphold the spirit of a joint planning process with First Nations claimed by the Far North Act, Nibinamik and the province must ensure that CLUP's do not replace consultation with First Nations. For the province, this means critical examination of how the spirit of partnership is upheld in process. Alternately, the province may admit the limited scope of partnership available when one party refuses to cede the power necessary for a truly joint process.

Values identified around cultural preservation and revitalization are strongly linked to values of self-determination and community engagement. According to Leanne Betasamosake Simpson,

“...the opposite of dispossession is not possession, it is deep, reciprocal, consensual attachment. Indigenous bodies don't relate to the land by possessing or having control over it. We relate to the land through connection-- generative, affirmative, complex, overlapping and nonlinear relationship. The reverse of dispossession within Indigenous thought then is Nishnaabeg intelligence, Nishnaabewin... This is our power" (Simpson, 2017, p 43).

Through this view, a self-determined approach to mapping and land use planning becomes essential for reclamation of "way of life", both through process and principle. Identification and reclamation of traditional governance structures, such as a consultative approach according to families and not traplines, is then a significant way of reclaiming the power to choose how decisions about the land are made and reestablishing "way of life" through process.

Intergenerational knowledge transfer, and the engagement of youth, was identified in reference to a feedback loop that will not only promote wellness for youth today, but will support the wellbeing of future youth. It is especially important for Nibinamik to centralize the voices of women, children, and 2SQ (two-spirit, queer Indigenous) community members, to disrupt the colonial erasure these voices face (Simpson, 2017). The mapping of shared territories, kinship networks, and consultation with other First Nations across the territory can be understood in relation to colonial state policies that promote the isolation of First Nations. These guiding 
project values seek to reconnect to "way of life" and re-story relationships within and across communities. In this way, Nibinamik seeks to leverage mapping in a new way, as a tool to promote cultural preservation, revitalization, and power.

One of the central values informing this mapping project is power and a desire to renegotiate the power dynamics shaping the relationship between Nibinamik and the province. Nibinamik's mapping project shares this in common with Indigenous communities around the globe. Recall that the province upholds that it has rights to exclusive jurisdiction, exclusive decision-making power, over "Crown land". NAN upholds that the province and First Nations in their territory have shared jurisdiction, shared decision-making power, over their "traditional territory" (Smith, 2015). Although the Far North Act creates provisions for the province and First Nations to engage in partnership to create CLUP's for crown land/traditional territory, the province maintains ultimate control over the process, and developed the policy in the absence of First Nations voices. Nibinamik can see that this is not indicative of true partnership, and perpetuates a model of top-down power that reinforces the dominance of the state over First Nations, offering only the illusion of ceded control. In this context, Nibinamik's aim to "declare the land" is a significant move that resists the province's claim to exclusive power. The failure of the province to engage in partnership with First Nations motivates Nibinamik's grass-roots approach to declaring power through counter-mapping. It must, however, be considered that counter-mapping may not be enough to disrupt centuries of state dominance (Hunt \& Stevenson, 2017). In the absence of a provincially-approved CLUP, Nibinamik's territory may face top-down imposition of a land use plan, and a corresponding map that re-stories the land according to the agenda of the province. Although disruption of state power is not easily done, the compounding values of this project promise purpose and benefits beyond the map itself. Restorying the land through a community-wide counter-mapping process holds the powerful potential for connecting to and preserving "way of life" through mobilized political action. 


\section{Moving Forward}

Nibinamik's substantive and procedural values for undertaking a counter-mapping project reveal a desire to preserve cultural knowledge, reconnect to "way of life", plan for the future of the community, and declare power in the face of state control. As they move forward with this endeavor, Nibinamik must keep community consultation and engagement at the front of mind. Through this project, we were able to identify key values and gather background knowledge on counter-mapping. With these findings, stakeholders can facilitate dialogue about the land use and mapping project within the community. Currently, the group of stakeholders involved in the project is not representative of the community at large, consisting only of adult men and one Elder. The inclusion of women, children, and youth is a recommended priority at this stage. As Nibinamik assembles a team of legal, economic development, land use planning, and mapping experts, it is recommended that experience with community engagement and values in grass-roots Indigenous Planning are prioritized as assets for all team members. A comprehensive community engagement strategy that informs project design, knowledge collection, training, participation, and dissemination, can support Nibinamik's vision of mobilizing the wealth of knowledge and expertise that exists within the community, especially as it pertains to "way of life".

On a site visit to Nibinamik, one community stakeholder was asked about the perceived benefits of this mapping project. In response, they shared a story:

"When the families came from Lansdowne, they were seen paddling away from the community. When they saw people leaving, they were emotional thinking they wouldn't see them again. An elder said that when they find what they are looking for, they will be back".

The community member further explained that the land and "way of life" is what they have been looking for. He reminded me that Nibinamik was founded by people who had traditional knowledge and a vision for the community's future, and today "There is so much knowledge in this community". As currently envisioned, Nibinamik's counter-mapping project holds the potential to mobilize community knowledge to re-story Nibinamik's traditional territory, away from state imposed boundaries, toward the reclamation of "way of life". With this potential comes the possibility of conflict stemming from unresolved claims to the power to determine the way of life for the people of Nibinamik, and Ontario's Far North. 


\section{References}

AFN supports nishnawbe aski nation's call to withdraw ontario's far north act. (2010). Canada NewsWire.

Aporta, C. (2011). Shifting perspectives on shifting ice: Documenting and representing inuit use of the sea ice. Canadian Geographer / Le Géographe Canadien, 55(1), 6-19.

Caquard, S., Pyne, S., Igloliorte, H., Mierins, K., Hayes, A., \& Taylor, D. R. F. (2009). A "Living" atlas for geospatial storytelling: The cybercartographic atlas of indigenous perspectives and knowledge of the great lakes region. Cartographica: The International Journal for Geographic Information and Geovisualization, 44(2), 83-100.

Cidell, J. (2008). Challenging the contours: Critical cartography, local knowledge, and the public. Environment and Planning A, 40(5), 1202-1218.

Crampton, J. W. (2009). Cartography: Performative, participatory, political. Progress in Human Geography, 33(6), 840-848.

Crampton, J. W. (2010). Mapping: A critical introduction to cartography and GIS. BPS Blackwell.

Coates, T. (2015). A Community Based History of Anishnaabe Communities that Signed Treaty 9 and Became the Fort Hope Indian Band (Part 1: Pre-contact to the Signing of Treaty 9).

Toronto, ON: Mamow Ki ken da ma win: Searching Together.

Corbett, J. (2009). Good practices in participatory mapping: A review prepared for International Fund for Agricultural Development.

Driben, P., \& Trudeau, R. S. (1983). When freedom is lost: The dark side of the relationship between government and the fort hope band. University of Toronto Press

Ethnographic Mapping Lab. (2018). Coast Salish Cultural Landscapes. University of Victoria. Retreived from: https://www.uvic.ca/socialsciences/ethnographicmapping/projects/culturallandscapes/index.php

Freeman, M. M. R. (2011). Looking back-and looking ahead-35 years after the inuit land use and occupancy project. Canadian Geographer / Le Géographe Canadien, 55(1), 20-31.

Gardner, H. L., Stephen R J Tsuji, McCarthy, D. D., Whitelaw, G. S., \& Tsuji, L. J. (2012). The far north act (2010) consultative process: A new beginning or the reinforcement of an unacceptable relationship in northern ontario, canada? International Indigenous Policy Journal, 3(2), 7. 
Gearheard, S., Aporta, C., Aipellee, G., \& O'Keefe, K. (2011). The igliniit project: Inuit hunters document life on the trail to map and monitor arctic change. Canadian Geographer / Le Géographe Canadien, 55(1), 42-55.

Goeman, M. (2008). (re)mapping indigenous presence on the land in native women's literature. American Quarterly, 60(2), 295-302.

Goeman, M. (2013). Mark my words: Native women mapping our nations. University of Minnesota Press.

Harley, J. B. (1989). Deconstructing the map. Cartographica, 26(2), 1-20.

Hunt, D. (2016). Nikîkîwân: Contesting settler-colonial archives through indigenous oral history. Canadian Literature, 230-231(230-231), 25

Hunt, D., \& Stevenson, S. A. (2017). Decolonizing geographies of power: Indigenous digital counter-mapping practices on turtle island. Settler Colonial Studies, 7(3), 372-392.

Johntson, J. T., \& Murton, B. (2007). Re/placing native science: Indigenous voices in contemporary constructions of nature. Geographical Research, 45(2), 121-129.

Long, J. S. (2006). How the commissioners explained treaty number nine to the ojibway and cree in 1905. Ontario History, 98(1), 1.

Louis, R. P., Johnson, J. T., \& Pramono, A. H. (2012). Introduction: Indigenous cartographies and counter-mapping. Cartographica: The International Journal for Geographic Information and Geovisualization, 47(2), 77-79.

Ineese-Nash, N. (2016). Nibinamik Historical Chronology. Mamow ki Ken da Ma win: Searching Together.

McCarthy, D. D. P., Whitelaw, G. S., Anderson, S., Cowan, D., McGarry, F., Robins, A., . . . Tsuji, L. J. S. (2012). Collaborative geomatics and the mushkegowuk cree first nations: Fostering adaptive capacity for community-based sub-arctic natural resource management. Geoforum, 43(2), 305-314.

Minkin, D., Whitelaw, G. S., Daniel D P McCarthy, \& Leonard J S Tsuji. (2014). Cultural protection, empowerment and land use planning: Identification of values in support of fort albany first nation, ontario, canada, community based land use planning. The Canadian Journal of Native Studies, 34(1), 129.

Olson, R., Hackett, J., \& DeRoy, S. (2016). Mapping the digital terrain: Towards indigenous geographic information and spatial data quality indicators for indigenous knowledge and traditional land-use data collection. The Cartographic Journal, 53(4), 348-355. 
Ontario Ministry of Natural Resources and Forestry. (2012). Far North of Ontario: Information about the Far North of Ontario and how to view the boundary in detail. Retreived from: https://www.ontario.ca/rural-and-north/far-north-ontario

Ontario Ministry of Natural Resources and Forestry. (2014). Far North Land Use Strategy: A Discussion Paper. Retreived from: https://dr6j45jk9xcmk.cloudfront.net/documents/3627/fnlusdiscussion-paper-2014-09-23-english.pdf

Ontario Ministry of Natural Resources and Forestry. (2015). The Far North Land Use Planning Initiative. Retreived from: https://www.ontario.ca/page/far-north-land-use-planning-initiative

Ontario Ministry of Natural Resources and Forestry. (2010). Far North Act. Retrieved from: https://www.ontario.ca/laws/statute/10f18

Pasternak, S. (2017). Grounded authority: The algonquins of barriere lake against the state. University of Minnesota Press.

Pickles, J. (1995). Ground truth: The social implications of geographic information systems. Guilford Press.

Ranva, O. (2015). The Sami Influence in Legislative Processes: Adoption of the Finnmark Land Act of 2005. Mapping indigenous presence: North scandinavian and north american perspectives. The University of Arizona Press.

Scassa, T., Engler, N. J., \& Taylor, D. R. F. (2015). Legal issues in mapping traditional knowledge: Digital cartography in the canadian north. The Cartographic Journal, 52(1), 41-50.

Shanley, K. W., \& Evjen, B. (2015). Mapping indigenous presence: North scandinavian and north american perspectives. The University of Arizona Press.

Sletto, B. (2009). Special issue: Indigenous cartographies. Cultural Geographies, 16(2), 147152.

Sletto, B. (2009). 'indigenous people don't have boundaries': Reborderings, fire management, and productions of authenticities in indigenous landscapes. Cultural Geographies, 16(2), 253277.

Smith, M. (2015). A reflection on first nations in their boreal homelands in ontario: Between a rock and a caribou. Conservation and Society, 13(1), 23-38.

Sudol, S. (2014). Ontario Ring of Fire's Astonishing World-Class Mining Potential. Huffington Post. Retreived from: http://www.huffingtonpost.ca/stan-sudol/ontario-ring-of-firesast_b_4809855.html 
Taylor, D. R. F. (2005). Cybercartography: Theory and practice (1st ed.) Elsevier.

Thom, B. (2009). The paradox of boundaries in coast salish territories. Cultural Geographies, 16(2), 179-205.

Thom, B., Colombi, B. J., \& Degai, T. (2016). Bringing indigenous kamchatka to google earth: Collaborative digital mapping with the itelmen peoples. Sibirica, 15(3), 1-30.

Tobias, T. N., Union of British Columbia Indian Chiefs, \& Ecotrust Canada. (2009). Living proof: The essential data-collection guide for indigenous use -and-occupancy map surveys. Ecotrust Canada.

Wainwright, J., \& Bryan, J. (2009). Cartography, territory, property: Postcolonial reflections on indigenous counter-mapping in nicaragua and belize. Cultural Geographies, 16(2), 153-178.

Whitelaw, G. S., McCarthy, D. D., \& Tsuji, L. J. S. (2012). The use of traditional environmental knowledge to resolve the issue of family-based traditional lands versus registered traplines: The victor diamond mine comprehensive environmental assessment scoping process. Canadian Journal of Native Studies, 32(2), 141.

Willow, A. J. (2013). Doing sovereignty in native north america: Anishinaabe counter-mapping and the struggle for land-based self-determination. Human Ecology, 41(6), 871-884.

Wood, D., \& Fels, J. (1992). The power of maps. Guilford Press. 